relapsing after stopping treatment for acute lymphoblastic leukaemia depends on the time that has elapsed since they stopped treatment. In children relapsing during the first six months or so there is a high risk of early marrow recurrence and they should be considered for marrow transplantation during second remission if there is a suitable donor. In patients relapsing later prolonged haematological remission is possible. We are presently studying the effect of more intensive induction and consolidation treatment in both groups of patients; whether this approach will increase the proportion of long-term survivors remains to be seen.

Further central nervous system prophylaxis is imperative for all children who have a bone-marrow recurrence after stopping treatment; intrathecal chemotherapy is the most appropriate method because it is less likely to compromise the delivery of systemic chemotherapy and avoids the undesirable effects of further cranial irradiation. The role of further "delayed" irradiation in long-term survivors remains unclear and will perhaps be elucidated by extrapolation from results of trials evaluating the necessity for routine irradiation in all newly diagnosed cases of acute lymphoblastic leukaemia.

We thank the Medical Research Council and the Leukaemia Research Fund for support, Mrs Carolyn Nelson for data collection, and Mrs Jean Bridger for secretarial help.

\section{References}

${ }^{1}$ Cornbleet MA, Chessells JM. Bone-marrow relapse in acute lymphoblastic leukaemia in childhood. Br Med F 1978;ii:104-6.

2 Ekert H, Ellis WM, Waters KD. Poor outlook for childhood acute lymphoblastic leukaemia with relapse. Med F Aust 1979;66:224-6.

${ }^{3}$ Rivera G. Recurrent childhood lymphocytic leukemia : out come of marrow relapses after cessation of therapy. In: Neth R, Gallo RC, Graf T, Mannweiler K, Winkler K. Modern trends in leukemia IV. Berlin: Springer Verlag (in press).

${ }^{4}$ Medical Research Council. Analysis of treatment in childhood leukaemia. II. Timing and the toxicity of combined 6-mercaptopurine and methotrexate maintenance therapy. Sr $\tilde{J}$ Haematol 1976;33:179-88.

${ }^{5}$ Medical Research Council. Anaiysis of treatment in childhood leukaemia. $\mathrm{V}$. Advantage of reducing chemotherapy during and immediately after cranial irradiation. Br $\mathcal{F}$ Cancer $1977 ; 36: 625-33$.

${ }^{6}$ Rapson NT, Cornbleet MA, Chessells JM, Bennett T, Hardisty RM. Immunosuppression and serious infections in children with acute lymphoblastic leukaemia: a comparison of three chemotherapy regimes. Br.F Haematcl 1980;45:41-52.

7 Chessells JM, Hardisty RM, Rapson NT, Greaves M. Acute lymphoblastic leukaemia in children: classification and prognosis. Lancet 1977 ;ii:1307-9

${ }^{8}$ Leventhal BG, Levine AS, Graw RG, Simon R, Freirich EJ, Henderson ES. Long term second remissions in acute lymphatic leukemia. Cancer $1975 ; 35: 1136-40$

${ }^{9}$ Hardisty RM, Norman PM. Meningeal leukaemia. Arch Dis Child 1967;42:441-7.

1" Rivera G, Aur RJA, Dahl GV, et al. Second cessation of therapy in childhood lymphocytic leukemia. Blood 1979;53:1114-20.

(Accepted 25. Yune 1981)

\title{
Oestrogen receptor proteins in malignant and fetal pancreas
}

\author{
BRIAN GREENWAY，M J IQBAL，P J JOHNSON， ROGER WILLIAMS
}

\begin{abstract}
High levels of high-affinity oestrogen binding were detected in cytosolic and nuclear fractions of tumour tissue from six patients with pancreatic carcinoma. Similar binding was found in fetal but not in normal adult pancreas, making derepression of fetal genes a possibility. Specific androgen binding was not detectable.

These findings suggest that anti-oestrogen treatment may offer a new approach to the treatment of pancreatic carcinoma.
\end{abstract}

\section{Introduction}

High levels of cytosolic oestrogen and androgen receptor binding have been detected in breast carcinoma tissue. ${ }^{2}$ High cytosolic oestrogen receptor binding may be used to predict an increased possibility of clinical response to anti-oestrogen treatment or hormone ablation. About $40^{\prime \prime}$ of patients with breast carcinoma do not respond to treatment, and this has been attributed to failure of the oestrogen receptor complex to bind to the nucleus. Recent evidence suggests that the detection of nuclear as well as cytosolic binding may give a better prediction of response. ${ }^{3}$ Cytosolic oestrogen receptors have been reported in several other human tumours ${ }^{4-7}$ including two cases of

Liver Unit, King's College Hospital and Medical School, London SE5 8R X

BRIAN GREENWAY, MRCP, FRCS, clinical research fellow

M J IQBAL, PHD, research fellow

P J JOHNSON, MRCP, senior lecturer in medicine

ROGER WILLIAMS, MD, FRCP, director and consultant physician pancreatic carcinoma ${ }^{8}$; we studied nuclear as well as cytosolic oestrogen binding in six specimens of malignant pancreatic tissue. In view of the possibility that the presence of steroid receptors in malignant pancreas might represent the derepression of fetal genes we also carried out studies with fetal pancreas. Since the specimens might have been contaminated with other competing proteins we estimated both the high-affinity, lowcapacity sex-hormone-binding globulin and the low-affinity, high-capacity human serum albumin, major oestrogen binding proteins.

\section{Patients and methods}

Six specimens of pancreatic carcinoma tissue were obtained, three at laparotomy (two from men aged 69 and 48 years and one from a woman aged 56) and three at necropsy within six hours after death (two from men aged 73 and 78 years and one from a woman aged 78). All specimens were stored in liquid nitrogen and studied within 10 days except the one obtained from the 73-year-old patient at necropsy, which was stored at $-20^{\circ} \mathrm{C}$ for five months. Histological examination confirmed ductular cell carcinoma in all cases.

Pancreatic tissue was obtained from five fetuses (12-14 weeks) aborted by the use of intrauterine prostaglandin and was used as pooled tissue of three and two specimens. Normal pancreas taken at necropsy within five hours after death from three men and one woman dying of unrelated diseases served as control tissue.

PREPARATION OF CYTOSOL AND NUCLEOSOL AND ESTIMATION OF RECEPTOR BINDING

Tissue samples were manipulated below $4 \mathrm{C}$ and homogenised in TED buffer (10 mmol TRIS, $1.5 \mathrm{mmol}$ EDTA, and $1 \mathrm{mmol}$ dithiothreitol/1, pH 7.4) using an Ultra-Turrax before centrifugation at 
Concentration of oestradiol binding sites in nuclear and cytosolic fractions of pancreatic carcinoma and fetal pancreas, and determination of competing proteins by immunodiffusion and stanolone binding

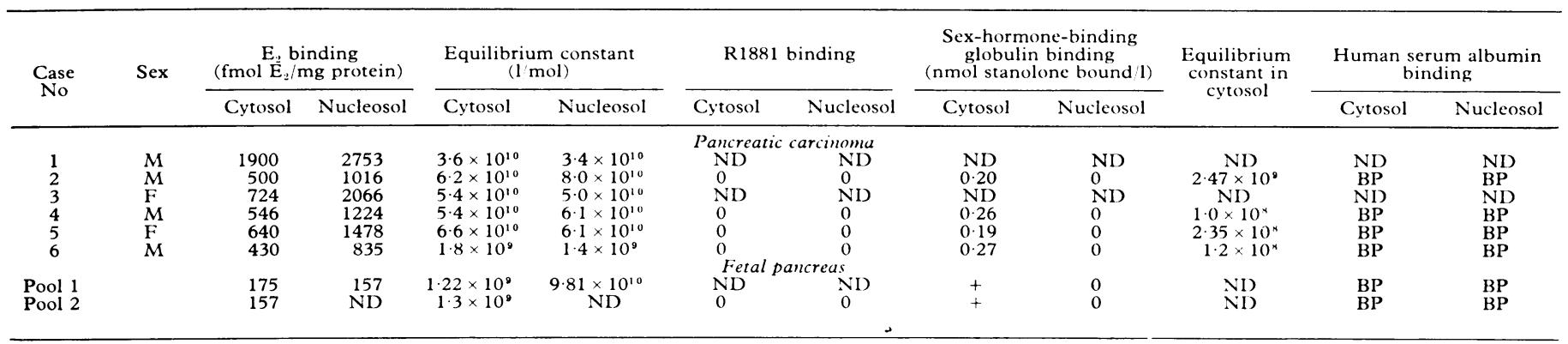

ND $=$ Not determined. $0=$ Not detected. $B P=$ Binding present in blue gel. $+=$ Present by immunodiffusion.

$200000 \mathrm{~g}$ for one hour. The supernatant was retained as cytosol. The pellet remaining when the cytosol was decanted was washed in TES buffer (10 mmol TRIS, $1 \mathrm{mmol} \mathrm{EDTA,} \mathrm{and} 250 \mathrm{mmol}$ sucrose/1, $\mathrm{pH} 7 \cdot 4$ ), centrifuged at $800 \mathrm{~g}$ for 10 minutes, and the supernatant discarded. The remaining pellet was homogenised in TSMK buffer (10 mmol TRIS, $250 \mathrm{mmol}$ sucrose, $5 \mathrm{mmol}$ magnesium chloride, and $25 \mathrm{mmol}$ potassium chloride/l, $\mathrm{pH} 7.5$ ) before filtration through a cellulose acetate plug, centrifuged for 15 minutes at $800 \mathrm{~g}$, and the supernatant discarded. The pellet was washed twice in TSMK buffer and then resuspended in TKED buffer containing $0.5 \mathrm{~mol}$ potassium chloride/l. The suspension was kept at $4^{\circ} \mathrm{C}$ for one hour and then centrifuged for 40 minutes at $15000 \mathrm{~g}$, the supernatant being retained for the study of high-affinity nuclear receptor binding.

Aliquots of cytosol and nucleosol $(500 \mu \mathrm{l})$ were incubated with increasing concentrations of either radioinert oestradiol or radioinert R1881 (a high-affinity synthetic androgen ${ }^{9}$ ) in the presence of a constant amount of tritiated oestradiol or tritiated R1881. The degree of non-specific binding was estimated in parallel experiments by incubating the $500 \mu \mathrm{l}$ aliquots with $700 \mathrm{nmol}$ of either radioinert oestradiol or R1881/1. The cytosol samples were incubated for four hours and the nucleosol for 18 hours, both at $4 \mathrm{C}$. Bound and free steroid were separated by a method based on the technique of Ginsburg et $a l^{10}: 200 \mu \mathrm{l}$ aliquots were applied in duplicate on to Sephadex LH20 columns, the dimensions of which allowed for the minimum dissociation of the high-affinity steroid receptor as described by Iqbal and Johnson. ${ }^{11} \mathrm{~A}$ discontinuous flow technique was used, the eluate being collected in phials containing scintillation mixture before being counted in a Packard-Tricarb liquid scintillation counter (efficiency $20 \%$ ). The sensitivity of the assay is approximately $5 \mathrm{fmol}$ steroid bound $/ \mathrm{mg}$ total soluble protein.

ESTIMATION OF SEX-HORMONE-BINDING GLOBULIN AND HUMAN SERUM ALBUMIN

Sex-hormone-binding globulin was detected by the double immunodiffusion technique with an antibody to the globulin raised in rabbits using the purified protein. ${ }^{12}$ Specificity was confirmed by the absence of precipitin lines after treatment with concanavalin A, which binds glycoproteins such as sex-hormone-binding globulin. In preparations in which sex-hormone-binding globulin was detected immunologically it was measured by means of the two-tier technique of Iqbal and Johnson. ${ }^{11}$ Stanolone (dihydrotestosterone), rather than oestradiol, is used as the steroid ligand since it has a higher affinity for the globulin and does not bind to corticosteroid-binding globulin. The presence of human serum albumin was detected indirectly by determining the amount of stanolone bound to this protein; this entails counting the Cibacron Blue 3GA Sepharose in the upper tier of the columns as described previously. ${ }^{11}$ Although this gel is highly specific for its binding of albumin, it may also bind the oestrogen receptor; this possibility was excluded by selective denaturation of the oestrogen receptor by heating. Cytosolic preparations were heated to $40 \mathrm{C}$ for 40 minutes in the presence of $100 \mathrm{mmol}$ calcium chloride/1, a procedure that denatures the oestrogen receptor but not sex-hormonebinding globulin. Specimens were then reanalysed by the two-tier technique for sex-hormone-binding globulin and albumin and also for receptor binding.

Scatchard plots were analysed by the method of Chamness and McGuire ${ }^{13}$ when there was evidence of more than one set of equivalent and homogeneous binding sites. Protein concentration was measured by the method of Lowry et al ${ }^{14}$ with human serum albumin as standard.

\section{Results}

High levels of high-affinity (equilibrium constant $10^{9}-10^{10} \mathrm{l} / \mathrm{mol}$ ) oestrogen receptor binding were found in all six cytoplasmic and nuclear fractions of pancreatic carcinoma and fetal pancreas but not in normal pancreas (table). After the specimens had been heated to $40 \mathrm{C}$ for 40 minutes high-affinity receptor binding was no longer detectable.

Sex-hormone-binding globulin, assessed by the immunodiffusion technique, was present in all cytosolic preparations examined; after the same preparations had been treated with concanavalin A, however, precipitin lines were absent. The amount of sex-hormone-binding globulin present, in terms of its ability to bind stanolone, was between $0 \cdot 19$ and $0 \cdot 27 \mathrm{nmol}$ stanolone bound $/ 1$, and did not change after the oestrogen receptor had been denatured by heating. Sex-hormonebinding globulin could not be detected in any of the nuclear fractions.

There was appreciable steroid binding in the Cibracon Blue gel in all nuclear and cytosolic fractions. This remained after the receptor had been inactivated by heating and can therefore be attributed to the presence of human serum albumin, which is characteristically unsaturable (figure).

No androgen receptor binding was detected in any of the malignant, normal, or fetal pancreatic tissue tested.

\section{Discussion}

The highly specific, high-affinity oestradiol receptor binding in neoplastic and fetal pancreas, determined by means of Scatchard analysis, indicates the presence of a single set of equivalent and homogeneous binding sites, similar to the oestrogen receptors found in tissues such as breast or uterus. The loss of this high-affinity binding with heating to $40^{\circ} \mathrm{C}$ for 40 minutes is further evidence of a true oestrogen receptor.

The concentrations of oestrogen receptor sites in the cytosol of the order of $10^{2}-10^{4} \mathrm{fmol} \mathrm{E}_{\mathrm{2}} / \mathrm{mg}$ total soluble protein are similar to those found by Stedman et $a l^{*}$ in two specimens of pancreatic carcinoma and comparable with levels found in many samples of breast carcinoma tissue. The appreciable oestrogen binding found in tissue obtained at necropsy, even after storage in one case at $-20^{\circ} \mathrm{C}$ for five months, was unexpected, since the receptor is considered to be highly labile. Namkung et $a l^{15}$ found that $80^{\prime}$ \% of the receptor activity in breast cancer was destroyed when the tissue was stored at $-70^{\circ} \mathrm{C}$ for one month, suggesting that if fresh tissue had been obtainable in all cases in the present study the concentration of binding sites might have been higher.

The failure to find specific binding in normal pancreas is at variance with the findings of Sandberg and Rosenthal. ${ }^{16}$ Their equilibrium constant of $10^{3} 1 / \mathrm{mol}$ suggests competition by sex-hormone-binding globulin, and the detection of this protein by immunodiffusion in all samples of normal pancreatic cytosol examined in our series lends support to this view. 
Fetal and malignant tissue share behavioural properties, including the production of the proteins $x$-fetoprotein and carcinoembryonic antigen. This has been attributed to derepression of fetal genes during the neoplastic process. ${ }^{17}$ The presence of oestrogen receptors in both fetal and neoplastic pancreatic tissue, as shown in the present study, may be another example of this phenomenon. Our data are also consistent, however, with the hypothesis of Jamieson et al ${ }^{1 \times}$ that pancreatic carcinoma arises from undifferentiated embryonic stem cells. They have shown in the rat that neoplastic acinar cells have cell surface characteristics in common with those of the 19-dayold embryonic pancreas. Furthermore, hormone receptors (such as those for insulin and prolactin) are in the fetal rat breast analage as early as 19 days. ${ }^{19}$

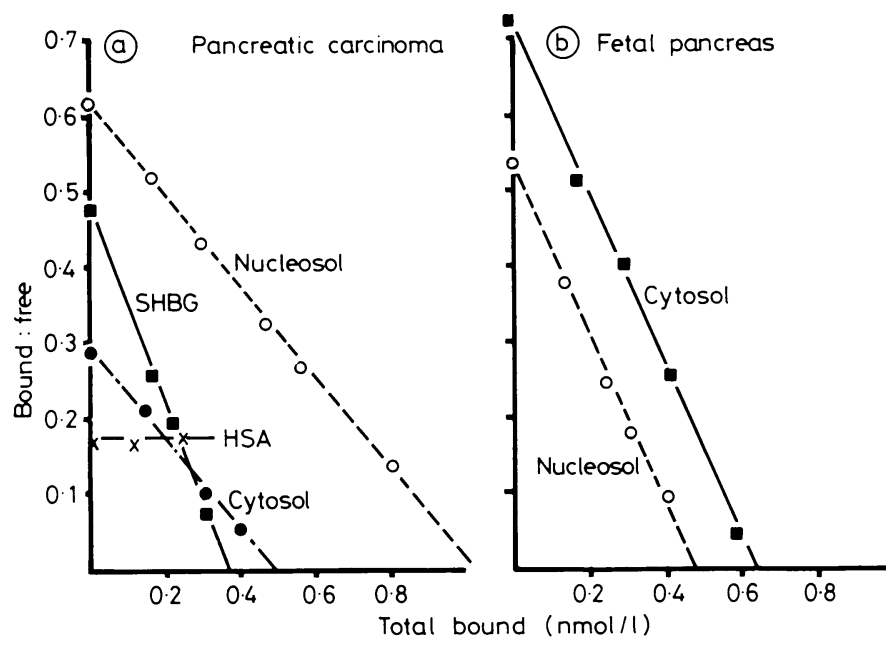

Scatchard analysis of (a) nuclear and cytoplasmic fractions of pancreatic tumour (case 2 ) and the competing proteins sex-hormone-binding globulin (SHBG) and human serum albumin (HSA) and $(b)$ nuclear and cytoplasmic fractions of fetal pancreas (pool 1). The equilibrium constants for fetal and malignant pancreas were derived by the method of Chamness and McGuire. ${ }^{13}$

At first, the finding of oestrogen receptors in fetal pancreas might seem surprising since oestrogens have only minor effects on organs outside the reproductive tract. It is well known, however, that testosterone, which may be more important to the growth of extragenital tissues, may act via the oestradiol receptor after being metabolised to oestrogen by the enzyme aromatase." The presence of specific cytoplasmic and nuclear oestrogen receptors in pancreatic carcinoma tissue suggests, as with breast carcinoma, that the growth of pancreatic carcinoma may be oestrogen dependent, which in turn implies that hormone manipulation might be of value in treatment.

We gratefully acknowledge the support of the Ned Foundation, the Cancer Research Campaign, and the Frances and Augustus
Newmann Foundation; also the help of Dr M Driver with the fetal pancreas, and Dr F K Habib, Edinburgh University, for kindly supplying the R1881.

ADDENDUM-Since this paper was completed we have examined three further specimens of malignant pancreatic tissue, including one nodal metastasis, of which two showed both cytosolic and nuclear oestrogen receptors. The third specimen, which was not the metastasis, was examined at five different sites and found not to contain any oestrogen receptors.

\section{References}

${ }^{1}$ Hawkins RA, Roberts MM, Forrest APM. Oestrogen receptors and breast cancer: current status. Br f Surg 1980;67:153-69.

2 Allegra JC, Lippman ME, Thompson EB, et al. Steroid hormone receptors in human breast tissue. Proceedings of the 69th meeting of the American Association for Cancer Research and the 14th meeting of the American Society of Clinical (Oncology. 1978, abstract C-118.

${ }^{3}$ MacFarlane JK, Fleiszer D, Fazekas AG. Studies on estrogen receptors and regression in human breast cancer. Cancer $1980 ; 45: 2998-3003$.

4 McClendon JE, Appleby D, Claudon DB, Donegan WL, DeCosse JJ. Colonic neoplasms. Tissue oestrogen receptor and carcinoembryonic antigen. Arch Surg 1977;112:240-1.

${ }^{5}$ Bojar H, I)reyfurst R, Balzar K, Staib W. Oestrogen binding components in human renal cell carcinoma. 7 Clin Chem Clin Biochem 1976;14: $521-6$.

${ }^{6}$ Keshgegian AA, Wheeler JE. Estrogen receptor protein in malignant carcinoid tumour. Cancer 1980;45:293-6.

7 Chaudhuri PK, Walker MJ, Briele HA, Beattie CW, Das Gupta TK. Incidence of estrogen receptor in benign nevi and human malignant melanoma. FAMA $1980 ; \mathbf{2 4 4}: 791-3$.

* Stedman KE, Moore GE, Morgan RT. Estrogen receptors in diverse human tumours. Arch Surg 1980;115:244-8.

${ }^{9}$ Bonne C, Raynaud J-P. Methyltrienolone, a specific ligand for cellular androgen receptors. Steroids $1975 ; 26: 227-32$

1" Ginsburg M, Greenstcin BS, Maclusky NJ, Morris II), Thomas PJ. An improved method for the study of high affinity steroid binding. Steroids $1974 ; \mathbf{2 3}: 773-91$.

1 Iqbal MJ, Johnson MW. Study of steroid protein binding by a novel "two tier" column employing Cibacron Blue F3G-A-Sepharose 4B. 7 Steroid Biochem 1977;8:977-83.

12 Iqbal MJ, Johnson MW. Purification and characterization of human sex hormone binding globulin. F Steroid Biochem 1979;10:535-40.

13 Chamness GC, McGuire WL. Scatchard plots: common errors in correction and interpretation. Steroids $1975 ; 26: 538-42$.

14 Lowry OH, Rosebrough NJ, Farr AI, Randall RJ. Protein measurement with the folin phenol reagent. 7 Biol Chem 1951;193:265-75.

${ }_{15}$ Namkung PC, Moe RE, Petra PH. Stability of oestrogen receptors in frozen breast tumour tissue. Cancer Res 1979;39:1124-5.

16 Sandberg AA, Rosenthal HE. Steroid receptors in exocrine glands; the pancreas and the prostate. F Steroid Biochem 1979;11:293-9.

17 Stonehill EH, Bendich A. Retrogenetic expression: the reappearance of embryonal antigens in cancer cells. Nature 1970;228:370-2.

${ }^{18}$ Jamieson JD, Ingber DE, Muresan V, et al. Cell surface properties of normal, differentiating and neoplastic pancreatic acinar cells. Cancer $1981 ; \mathbf{4 7} \cdot 1516-25$

19 Topper YJ, Freeman CS. Multiple hormone interaction in the developmental biology of the mammary gland. Physiol Rev 1980;60:1049-107.

20 Bardin CW, Catterall JF. Testosterone: a major determinant of extragenital sexual dimorphism. Science 1981 ;211:1285-94.

(Accepted 6 fuly 1981) 